\title{
3D cell bioprinting of self-assembling peptide-based hydrogels
}

DOI:

10.1016/j.matlet.2016.12.127

Document Version

Accepted author manuscript

Link to publication record in Manchester Research Explorer

\section{Citation for published version (APA):}

Raphael, B., Khalil, T., Workman, V. L., Smith, A., Brown, C. P., Streuli, C., Saiani, A., \& Domingos, M. (2016). 3D cell bioprinting of self-assembling peptide-based hydrogels. Materials Letters, 190, 103-106.

https://doi.org/10.1016/j.matlet.2016.12.127

\section{Published in:}

Materials Letters

\section{Citing this paper}

Please note that where the full-text provided on Manchester Research Explorer is the Author Accepted Manuscript or Proof version this may differ from the final Published version. If citing, it is advised that you check and use the publisher's definitive version.

\section{General rights}

Copyright and moral rights for the publications made accessible in the Research Explorer are retained by the authors and/or other copyright owners and it is a condition of accessing publications that users recognise and abide by the legal requirements associated with these rights.

\section{Takedown policy}

If you believe that this document breaches copyright please refer to the University of Manchester's Takedown Procedures [http://man.ac.uk/04Y6Bo] or contact uml.scholarlycommunications@manchester.ac.uk providing relevant details, so we can investigate your claim.

\section{OPEN ACCESS}




\section{$3 D$ cell bioprinting of self-assembling peptide-based hydrogels}

Bella Raphael $^{\mathrm{a}}$, Tony Khalil ${ }^{\mathrm{b}}$, Victoria L. Workman ${ }^{\mathrm{c}, \mathrm{f}}$, Andrew Smith ${ }^{\mathrm{c}, \mathrm{f}}$, Cameron P Brown ${ }^{\mathrm{d}}$, Charles Streulli $^{\mathrm{a}, \mathrm{e}}$, Alberto Saiani ${ }^{\mathrm{c}, \mathrm{f}}$, Marco Domingos ${ }^{\mathrm{a}, \mathrm{f}^{*}}$

${ }^{a}$ Faculty of Biology, Medicine and Health, The University of Manchester, UK

${ }^{\mathrm{b}}$ School of Mechanical, Aerospace and Civil Engineering, The University of Manchester, UK.

${ }^{c}$ School of Materials, The University of Manchester, UK

${ }^{\mathrm{d}}$ Botnar Research Centre, NDORMS, University of Oxford, UK.

${ }^{\mathrm{e}}$ Wellcome Trust Centre for Cell Matrix Research

${ }^{\mathrm{f}}$ Manchester Institute of Biotechnology, The University of Manchester, Manchester, UK.

\section{*Corresponding author}

Marco Domingos, School of Mechanical, Aerospace and Civil Engineering, University of Manchester, Manchester, UK. Tel.: +44 (0) 1613064889; E-mail address:

marco.domingos@manchester.ac.uk 


\begin{abstract}
Bioprinting of 3D cell-laden constructs with well-defined architectures and controlled spatial distribution of cells is gaining importance in the field of Tissue Engineering. New 3D tissue models are being developed to study the complex cellular interactions that take place during both tissue development and in the regeneration of damaged and/or diseased tissues. Despite advances in 3D printing technologies, suitable hydrogels or 'bioinks' with enhanced printability and cell viability are lacking. Here we report a study on the 3D bioprinting of a novel group of self-assembling peptide-based hydrogels. Our results demonstrate the ability of the system to print well-defined 3D cell laden constructs with variable stiffness and improved structural integrity, whilst providing a cell-friendly extracellular matrix "like" microenvironment. Biological assays reveal that mammary epithelial cells remain viable after 7 days of in vitro culture, independent of the hydrogel stiffness.
\end{abstract}

Keywords: Tissue Engineering, 3D Printing, Cell encapsulation, Hydrogels, Epithelial cells.

\title{
1. Introduction
}

The introduction of automated systems, in particular Additive Manufacturing (AM) techniques in the field of Tissue Engineering (TE) has promoted the establishment of a new area of research called Biofabrication [1]. As recently reported by Groll et al, Biofabrication can be defined as "the automated generation of biologically functional products with structural organization from living cells, bioactive molecules, biomaterials, cell aggregates such as micro-tissues, or hybrid cell-material constructs, through Bioprinting or Bioassembly and subsequent tissue maturation processes" [1]. Therefore the term Bioprinting can be employed to classify processes that combine different biomaterials, cells and biological molecules in order to generate 3D constructs/scaffolds with well-defined internal/external geometries and optimized biomechanical properties [2]. The methodology by which 3D porous scaffolds are seeded with cells and cultured in vitro prior to implantation, also known as a "top-down" approach, has improved our ability to design tissue analogues [3]. They have enhanced cell-cell and cell-ECM (extracellular-matrix) interactions, 3D cell spatial distributions, higher cell densities and fully interconnected pore networks for vascularization and media diffusion [4]. The benefits, when compared to cell-based strategies, are clear and extensively reported in the literature [5-6]. However this approach is still hindered by the inability of the scaffold to promote homogeneous cell distributions, or to mimic the native ECM microenvironment [6]. To address these issues, a "bottom-up" approach, combining Bioprinting and highly hydrated polymers with encapsulated cells have been investigated [4]. The range of 
manufacturing systems available is wide and can be classified into extrusion-based; binder jetting (or Ink Jet); and vat photo-polymerization (or laser-based) categories [7-9]. Different natural and synthetic hydrogels are used, for example Alginate, Gelatine, Hyaluronic Acid (HA), Polyethylene Glycol (PEG), Polyvinyl Alcohol (PVA), etc. [10-15]. Despite a possible release of toxic products during degradation and the low biocompatibility, synthetic hydrogels are still preferred for Bioprinting, as they allow for fine tuning of both chemical and physical properties while degrading at a controlled rate. The material requirements for Bioprinting are complex and often antagonistic. Low viscosity, low stiffness and low crosslinking densities enable cell migration, nutrient diffusion and neo tissue formation. High viscosity, high yield stress and rapid gelation ensure both the geometrical/dimensional accuracy of the constructs as well the post printing mechanical stability [14]. Ideally a compromise between the physicochemical (i.e. rheological) and biological properties of the hydrogel should be achieved to ensure the printing of constructs with high cell viability. For that purpose, different strategies have been proposed encompassing blending of the hydrogel material with gelatines, printing hybrid scaffolds using a thermoplastic as a structural reinforcement, photocrosslinking as a post-curing mechanism, physical crosslinking of spider silk recombinant proteins or dual stage crosslinking [10, 16-20]. While effective in increasing the mechanical stability of the constructs, these approaches generally require long fabrication times as well as the use of high temperatures and/or UV radiation, which can have detrimental effects on cell viability [21]. Here we describe a new methodology for 3D Bioprinting of cell-laden constructs with high geometrical definition, mechanical stability and cell viability. This is based on the use of a novel commercial selfassembling peptide based hydrogel (PeptiGelDesign.Ltd), that utilizes specific synthetic peptides that selfassemble from fluid precursors into a nanofibrous hydrogel when presented with physiological level ionic strengths. This 3-dimensional hydrogel matrix promotes cell growth and migration. Through optimization of the printing parameters, we show the ability of the system to print both soft and stiff hydrogels without compromising the viability of encapsulated cells. Furthermore, we demonstrate the potential of the hydrogel system for direct printing of viable biological constructs. These have tuneable mechanical properties, and do not need physical or chemical post processing.

\section{Experimental Section}

\subsection{Materials}

Peptide hydrogels were purchased from PeptiGelDesign (Cheshire, UK): Alpha1, AlphaProB. Alpha1 has G' (oscillatory shear modulus) values in the range of $\sim 10 \mathrm{kPa}$ and AlphaProB has G' values of $\sim 1 \mathrm{kPa}$ after media addition (Further information on the hydrogels can be obtained upon request from PeptiGelDesign 
www.peptigeldesign.com). LIVE/DEAD assay (Invitrogen), DMEM-F12, PBS and Trypsin were purchased from Sigma (Sigma Aldrich, UK).

\subsection{Cell Culture and hydrogel encapsulation}

EpH4 (mammary epithelial cells) were cultured in DMEM-F12 supplemented with 5\% FCS, $250 \mu$ insulin and $1 \%$ Pencillin/Streptomycin. Cells at passage 4 were suspended at a concentration of $4 \times 10^{6}$ cells ml $^{-1}$ in $2 \mathrm{ml}^{\text {of }}$ hydrogel solution. After complete homogenization the cell-gel solution was transferred to the bioprinting system cartridge and immediately printed into 6-well culture plates.

\section{2. $3 D$ cell bioprinting of self-assembling peptide based hydrogels}

The 3D printing of cell-laden hydrogel constructs was performed using a commercial extrusion-based AM system called 3D Discovery (regenHU, Villaz-St-Pierre, Switzerland). Initially, Disc-shape constructs with an outer diameter of $10 \mathrm{~mm}$, lay-down pattern of $0 / 90^{\circ}$, filament distance (FD) of $550 \mu \mathrm{m}$ (horizontal plane), layer thickness (LT) of $500 \mu \mathrm{m}$ and height of $1 \mathrm{~mm}$ were directly designed in the BioCAD software (regenHU, Villaz-St-Pierre, Switzerland). Subsequently, using an extrusion nozzle of $300 \mu \mathrm{m}$, constant deposition velocity (DV) of $10 \mathrm{~mm} / \mathrm{s}$, dosing distance of $0.1 \mathrm{~mm}$, and varying the extrusion pressure (EP) between $0.2-1 \mathrm{~Pa}$, multiple constructs were printed in order to find the optimal processing parameters for both soft (AlphaProB) and stiff (Alpha 1) hydrogels. After printing, cell constructs were supplied with culture media and incubated for 7 days at $37^{\circ} \mathrm{C}$ and $5 \% \mathrm{CO} 2$ in a humidified incubator.

\subsection{Cell viability}

Cell viability was determined by LIVE/DEAD assay (Sigma) consisting of calcein $(2 \mu \mathrm{M})$ as a marker for viable cells and propidium iodide $(1.5 \mu \mathrm{M})$ as a marker for dead cells. Observations were made by fluorescence microscopy (Zeiss LSM 700) with $494 \mathrm{~nm}$ (green, calcein) and $535 \mathrm{~nm}$ (red, propidium iodide) emission filters.

\subsection{Atomic Force Microscopy (AFM)}

Scanning probe microscopy was performed on a MFP-3D Atomic Force Microscope (Asylum Research, High Wycombe, UK), with an AC240TS probe $(\mathrm{k}=2.04 \mathrm{Nm}-1$, Olympus, Japan). AMFM nanomechanical mapping [22] and loss-tangent imaging [23] were applied, with measurements based on the shift in the probe's resonant frequencies dependent on the strength of the interaction, or tip-sample contact force [24].A tip correction factor was calculated based on the known compressive Young's modulus of a polycaprolactone calibration sample (300 MPa). Three $5 \mu \mathrm{m} \times 5 \mu \mathrm{m}$ areas were then randomly selected and measured from each material. $512 \times 512$ pixel maps of height, Young's modulus and loss tangent were recorded for each image. 


\section{Results and Discussion}

\subsection{D cell bioprinting of hydrogel constructs}

One of the major challenges in 3D cell printing is the ability to produce biological constructs with well-defined geometries and structural integrity, which both avoids the collapse of printed pores and guarantees cell viability. This becomes particularly challenging when the stiffness of the hydrogels is reduced, in order to increase cell viability. Initially we optimized the printing process parameters, namely EP and valve opening time (Table 1). We then examined the ability of the system to print 3D cell-laden constructs of mammary epithelial cells using both soft and stiff hydrogels (Fig 1). Our results revealed a high structural integrity and geometrical/dimensional accuracy of the printed cell-laden constructs.

\begin{tabular}{cccccc}
\hline \multicolumn{5}{c}{ Process Parameters } \\
\hline & $\begin{array}{c}\text { EP } \\
(\mathrm{Pa})\end{array}$ & $\begin{array}{c}\mathrm{DV} \\
(\mathrm{mm} / \mathrm{s})\end{array}$ & $\begin{array}{c}\text { Dosing } \\
\text { distance }(\mathrm{mm})\end{array}$ & $\begin{array}{c}\text { Valve opening } \\
\text { time }(\mu \mathrm{s})\end{array}$ & $\begin{array}{c}\text { Temperature } \\
\left({ }^{\circ} \mathrm{C}\right)\end{array}$ \\
\hline $\begin{array}{c}\text { PGD- } \\
\text { AlphaProB } \\
\text { PGD-Alpha 1 }\end{array}$ & 0.2 & 10 & 1 & 400 & 37 \\
\hline
\end{tabular}

Table 1: Optimal process parameters for 3D printing of soft and stiff cell-laden hydrogel constructs.

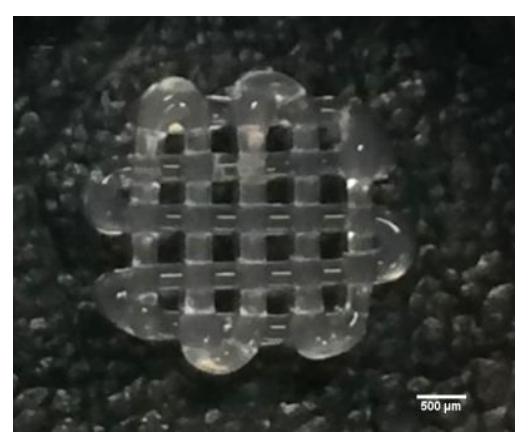

Figure 1: Top view of 3D printed mammary epithelial cell-laden construct (Alpha 1 hydrogel) with two layers of square interconnected pores of $250 \mu \mathrm{m}$ and filament diameter of $300 \mu \mathrm{m}$ (Scale bar: $500 \mu \mathrm{m}$ )

\subsection{Cell viability}

The viability of printed cells can be influenced by a detrimental effect of shear stresses induced by the extrusion-based process, namely nozzle diameter and extrusion pressure. However our gel-printing methods 
revealed large number of viable cells, independent of the hydrogel stiffness, after 7 days of culture. These cells had proliferated and started to form clusters in AlphaProB (Fig 2). The observed high level of cell viability and evidence of proliferation confirms that the printing parameters were not detrimental to cell health. The formation of aggregates, and the differences seen in the morphology of the cells encapsulated in stiff or soft gels, may be related to the rheological properties of the gel; further work to characterize this effect is currently underway. Our data reiterate previous findings that this family of self-assembling hydrogels is conducive to cell survival and growth [25-27]

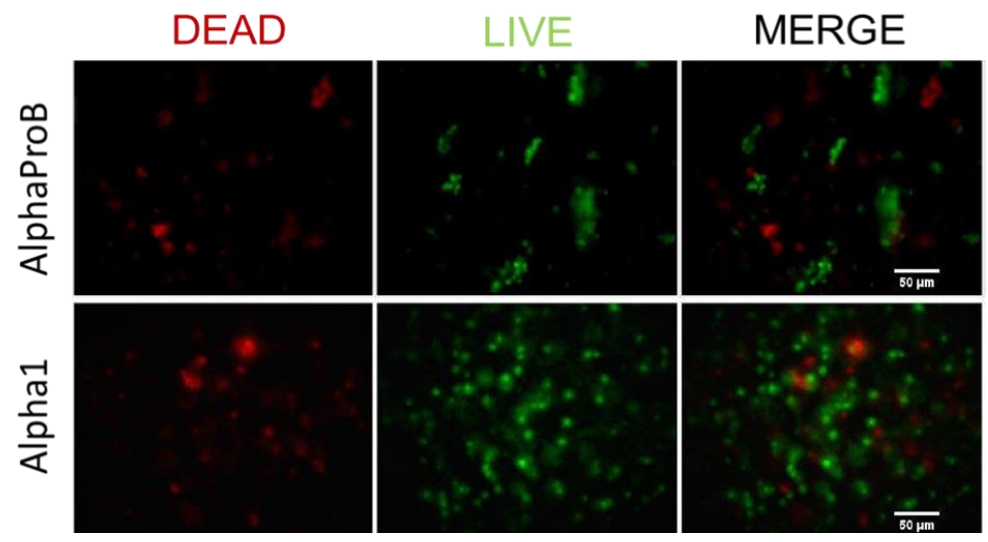

Figure 2: Fluorescence microscopy images of 3D printed mammary epithelial cell-laden constructs showing viable (green, calcein) and dead cells (red, propidium iodide) on both soft (AlphaProB) and stiff (Alpha1) hydrogels.

\subsection{AFM analysis}

Nano- to micro-scale structural and mechanical cues are associated with biological responses, in both native ECMs and synthetic constructs [28-31] Although the mechanistic understanding of this association is in its infancy, this level of structure in terms of assembly, control, and communication within the biological environment, are all key for biomaterials development [32-34]. We found that the nano-scale topographical appearance of unseeded samples were qualitatively similar, showing surface features on the order of 50-100 nm (Fig 3a,b). "Stiff” hydrogels however, consistently displayed large topographical features on the micro-scale, due to increased structural integrity maintaining the printed morphology (Fig 3b). In contrast, the "soft" hydrogel material flattened under surface tension to produce a smooth micro-scale topography. Calculated over $5 \mu \mathrm{m} \times 5 \mu \mathrm{m}$, roughness $(\mathrm{Rq})$ was 0.7 and $11 \mathrm{~nm}$ for soft and stiff hydrogels, with low-level roughness of Rq 0.6 and $2 \mathrm{~nm}$, respectively (calculated over $500 \mathrm{~nm}$ x $500 \mathrm{~nm}$ ). Nano-mechanical properties were similarly varied between sample groups (Fig 3c,d). The self-assembled peptide components themselves showed opposite trends to the macro-scale properties. Nano-scale Young's moduli of Alpha1 and AlphaProB were $330 \pm 55 \mathrm{MPa}$ vs 
$430 \pm 240 \mathrm{MPa}$ ( $p \rightarrow 0$, two-sided Wilcoxon rank sum test), compared to their macroscopic moduli on the order of $10 \mathrm{kPa}$ and $1 \mathrm{kPa}$ respectively. Loss tangent values were similarly distributed $(p \rightarrow 0)$, with peptide components from macroscopically "soft" hydrogels more effectively damping, or dissipating, mechanical contact (Fig 3d). While bulk elastic [35] and viscous [36] properties have been shown to modulate cell response, the effects of local fibre properties within gels and matrices are less understood. It is not clear whether these properties can be decoupled in the current hydrogel system, however the range of mechanical properties observed at the different scales indicates strong potential for modulation of cell response via control of hierarchical viscoelasticity.
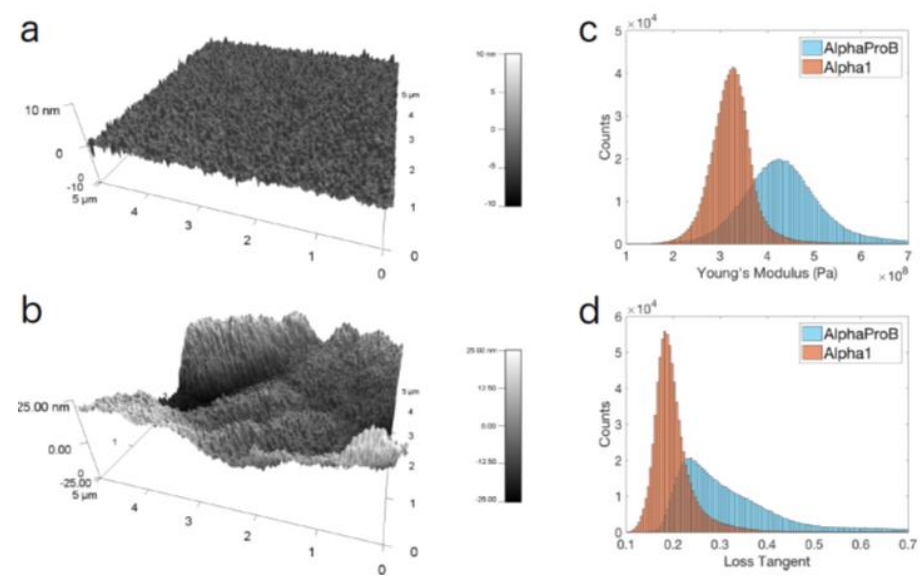

Figure 3: (a,b) Scanning probe microscopy shows representative $5 \mu \mathrm{m} \times 5 \mu \mathrm{m}$ height images of soft and stiff unseeded hydrogels respectively. (c) Distribution of Young's moduli. (d) Distribution of Loss tangent.

\section{Conclusions}

The successful application of 3D Bioprinting in the production of cell-laden constructs is required for the ability to develop suitable hydrogels or 'bioinks' with enhanced printability and cell viability. Here we report a novel methodology for the 3D printing of self-assembling peptide-based hydrogel constructs with encapsulated epithelial cells. Based on the optimization of the process parameters, we demonstrate the feasibility of the system to print 3D matrices with well-defined architectures and improved structural integrity. After 7 days of culture, biological results confirm that encapsulated mammary epithelial cells remain viable and start to proliferate, independently of the hydrogel stiffness. The potential of this new methodology relies on the possibility to manipulate, in a simple manner, the ECM microenvironment through 3D printing of hydrogels with adjustable hierarchical stiffness, thereby modulating cellular responses. 


\section{Acknowledgments}

The authors would like to thank the EPSRC for funding this research (Grant no: EP/K016210/1). In addition, core funding for the Wellcome Trust Centre for Cell-Matrix Research (088785/Z/09/Z), from the Welcome Trust, United Kingdom, supported this work.

\section{References}

[1] Groll J, Boland T, Blunk T, Burdick JA, Cho DW, Dalton PD, Derby B, Forgacs G, Li Q, Mironov VA, Moroni L, Nakamura M, Shu W, Takeuchi S, Vozzi G, Woodfield TBF, Xu T, Yoo JJ, Malda J, Biofabrication: reappraising the definition of an evolving field. Biofabrication 8 (2016) 013001.

[2] Melchels FPW, Domingos MAN, Klein TJ, Malda J, Bartolo PJ. Hutmacher DW. Additive manufacturing of tissues and organs, Prog. Polym. Sci. 37 (2012) 1079-1104.

[3] Caetano G, Violante R, Sant`Ana AB, Murashima AB, Domingos M, Gibson A, Bártolo P, Frade MA. Cellularized versus decellularized scaffolds for bone regeneration. Mater. Lett. 182 (2016) 318-322

[4] Oliveira SM, Reis RL, Mano JF. Towards the design of 3D multiscale instructive tissue engineering constructs: Current approaches and trends, Biotechnol. Adv. 33 (2015) 842-855.

[5] Demirbag B, Huri PY, Kose GT, Buyuksungur A, Hasirci V. Advanced cell therapies with and without scaffolds. Biotechnol. J. 6 (2011) 1437-1453

[6] Hollister SJ. Porous scaffold design for tissue engineering. Nat. Mater. 4 (2005) 518-524.

[7] Melchels FPW, Blokzijl MM, Levato R, Peiffer QC, Ruijter M, Hennink WE, Vermonden T, Malda J. Hydrogel-based reinforcement of 3D bioprinted constructs. Biofabrication 8 (2016) 035004.

[8] Murphy SV, Skardal A, Atala A. Evaluation of hydrogels for bio-printing applications. J. Biomed. Mater. Res. 101A (2013) 272-284.

[9] Wang Z, Abdulla R, Parker B, Samanipour R, Ghosh S, Kim K. A simple and high-resolution stereolithography-based 3D bioprinting system using visible light crosslinkable bioinks. Biofabrication 7 (2015) 045009 .

[10] Billiet T, Gevaert E, Schryver TD, Cornelissen M, Dubruel P. The 3D printing of gelatin methacrylamide cell-laden tissue-engineered constructs with high cell viability. Biomaterials 35 (2014) 49-62.

[11] Censi R, Schuurman W, Malda J, Dato G, Burgisser PE, Dhert WJA, Nostrum CF, Martino P, Vermonden T, Hennink WE. A Printable Photopolymerizable Thermosensitive p(HPMAm-lactate)-PEG Hydrogel for Tissue Engineering. Adv. Funct. Mater. 21 (2011) 1833-1842.

[12] Markstedt K, Mantas A, Tournier I, Ávila HM, Hägg D, Gatenholm P. 3D Bioprinting Human Chondrocytes with Nanocellulose-Alginate Bioink for Cartilage Tissue Engineering Applications. Biomacromolecules 16 (2015) 1489-1496.

[13] Billiet T, Vandenhaute M, Schelfhout J, Vlierberghe SV, Dubruel P. A review of trends and limitations in hydrogel-rapid prototyping for tissue engineering. Biomaterials 33 (2012) 6020-6041.

[14] Chimene D, Lennox KK, Kaunas RR, Gaharwar AK. Advanced Bioinks for 3D Printing: A Materials Science Perspective. Ann. Biomed. Eng. 44 (2016) 2090-2102.

[15] Jungst T, Smolan W, Schacht K, Scheibel T, Groll J. Strategies and Molecular Design Criteria for 3D Printable Hydrogels, Chem. Rev. 116 (2016) 1496-1539.

[16] Ouyang L, Yao R, Zhao Y, Sun W. Effect of bioink properties on printability and cell viability for 3D bioplotting of embryonic stem cells. Biofabrication 8 (2016) 035020.

[17] Pati F, Shim J-H, Lee J-S, Cho D-W. 3D printing of cell-laden constructs for heterogeneous tissue regeneration. Manufacturing Letters 1 (2013) 49-53.

[18] Zehnder T, Sarker B, Boccaccini AR, Detsch R. Evaluation of an alginate-gelatine crosslinked hydrogel for Bioplotting, Biofabrication 7 (2015) 025001

[19] Schacht K, Jungst T, Schweinlin M, Ewald A, Groll J, Scheibel T. Biofabrication of Cell-Loaded 3D Spider Silk Constructs. Angew. Chem. Int. Ed. 54 (2015) 2816 -2820

[20] Dubbin K, Hori Y, Lewis KK, Heilshorn SC. Dual-Stage Crosslinking of a Gel-Phase Bioink Improves Cell Viability and Homogeneity for 3D Bioprinting. Adv. Healthcare Mater. 5 (2016) 2488-2492

[21] Kang LH, Armstrong PA, Lee LJ, Duan B, Kang KH, Butcher JT. Optimizing Photo-Encapsulation Viability of Heart Valve Cell Types in 3D Printable Composite Hydrogels. Ann. Biomed. Eng. (2016) doi:10.1007/s10439-016-1619-1 
[22] Proksch, R. and R.C. Callahan, Material property measurements using multiple frequency atomic force microscopy. 2011, Google Patents.

[23] Proksch, R. and D.G. Yablon, Loss tangent imaging: Theory and simulations of repulsive-mode tapping atomic force microscopy. Applied Physics Letters, 2012. 100(7): p. 073106-3.

[24] Giessibl, F.J., Forces and frequency shifts in atomic-resolution dynamic-force microscopy. Physical Review B, 1997. 56(24): p. 16010-16015.

[25] Mujeeb A, Miller AF, Saiani A, Gough JE. Self-assembled octapeptide scaffolds for in vitro chondrocyte culture. Acta Biomat. 9 (2013) 4609-4617.

[26] Wan S, Borland S, Richardson SM, Merry CLR, Saiani A, Gough JE. Self-assembling peptide hydrogel for intervertebral disc tissue engineering .Acta Biomat. (2016) in press.

[27] Diaz LAC, Saiani A, Gough JE, Miller AF. Human osteoblasts within soft peptide hydrogels promote mineralisation in vitro. J. Tissue Eng. 5 (2014) 1-12.

[28] Dvir T, Timko BP, Kohane DS, Langer R. Nanotechnological strategies for engineering complex tissues.

Nature Nanotechnol. 6 (2011) 13-22.

[29] Tsang K, Cheung MC, Chand D, Cheah KS. The developmental roles of the extracellular matrix: beyond structure to regulation. Cell Tissue Res. 339 (2010) 93-110.

[30] Lord MS, Foss M, Besenbacher F. Influence of nanoscale surface topography on protein adsorption and cellular response. Nano Today, 5 (2010) 66-78.

[31] Streuli CH. Integrins as architects of cell behaviour. Mol. Biol. Cell, 27 (2016) 2885-2888.

[32]Whitesides GM. The 'right' size in nanobiotechnology. Nat. Biotechnol. 21 (2003) 1161-1165.

[33] Stevens MM, George JH. Exploring and engineering the cell surface interface. Science, 310 (2005) 11351138.

[34] Brown CP. Advancing musculoskeletal research with nanoscience. Nat. Rev. Rheumatol. 9 (2013) 614-623. [35] Engler AJ, Sweeney HL, Discher DE. Matrix Elasticity Directs Stem Cell Lineage Specification. Cell, 126 (2006) 677-689.

[36] Cameron AR, Frith JE, Cooper-White JJ. The influence of substrate creep on mesenchymal stem cell behaviour and phenotype. Biomaterials, 32 (2011) 5979-5993 